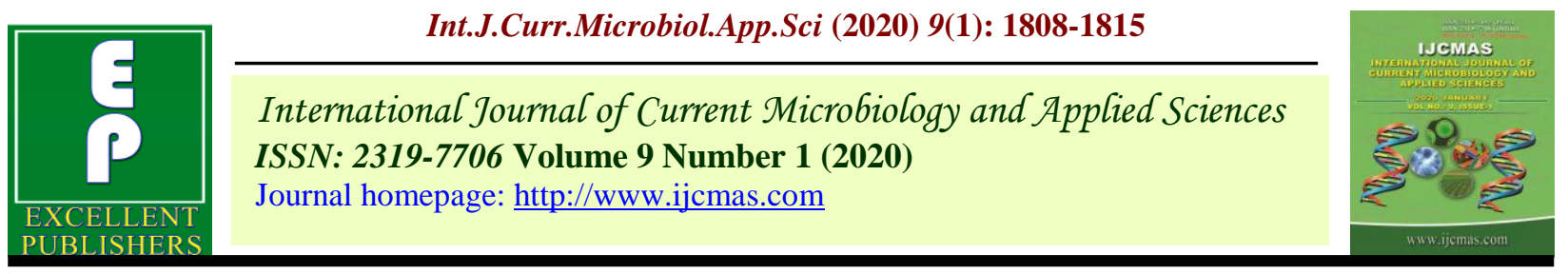

Original Research Article

https://doi.org/10.20546/ijcmas.2020.901.202

\title{
Microbial Assessment of Bio-medical Waste from Different Health Care Units of Bikaner
}

\author{
Rajani Joshi, Rakesh Rao, Manohar Sain, Pankaj Mangal* and Paramjeet Kaur
}

Animal biomedical waste disposal technology centre, Rajasthan University of Veterinary and Animal Sciences, Bikaner- 334001, Rajasthan, India

*Corresponding author

\section{A B S T R A C T}

\section{Keywords}

Biomedical waste, Hazards, Bacillus cereus

Article Info

\section{Accepted:}

15 December 2019

Available Online:

20 January 2020
Biomedical waste has been one of the major headaches of any hospital. Eighty percent waste generated from the hospitals is general waste and the remaining twenty percent comes under the biomedical waste categories. If this waste is not properly managed, it is dangerous for people, animals and environment due to its high harmful potential. In the present investigation, aerobic bacteria like Escherichia coli (32\%), Staphylococcus aureus (28\%), and Bacillus spp. (10\%) were isolated from the biomedical waste. These bacterial strains were morphologically identified and confirmed by using primary and secondary biochemical tests. Clearly there is a need of awareness to the hazards associated with improper biomedical waste disposal. Lack of apathy to the concept of waste management is a major stymie to the practice of waste disposal.

\section{Introduction}

Biomedical waste is any wastes generated during the diagnosis, treatment or immunization of animals and human beings or in research activity. Biomedical wastes are extremely hazardous type of waste and if not managed properly, can lead to serious health and environment problems (GOI, 1998). Biomedical wastes are divided into infected and non-infected wastes. Non infected wastes may be disposed by land filling as done for municipal wastes (Omrani et al., 2007).
Infectious waste may contain pathogens, which can infect people through a number of routes, such as punctures, abrasions or lacerations of the skin, via the mucous membranes, by inhalation or ingestion. It consists wholly or partly of human or animal tissues, blood or body fluids, excretions, drugs or other pharmaceutical products, swabs or dressings or syringes, needles or other sharp instruments, being waste which unless rendered safe may prove hazardous (including microbial (infectious), pharmacological and/or physical [e.g. sharps] 
dangers to any person coming into contact with it (Jang et al., 2006 and Nemathaga et al., 2008) But the infected wastes require appropriate treatment processes prior to disposal. When the infectious component gets mixed with the general non-infectious waste, the entire mass becomes potentially infectious.

Infectious or hazardous hospital waste represents only a small part of the total medical waste; yet, because of ethical questions and potential health risks, it is a focal point of public interest. The pathogens present in the waste can leach out and contaminate the environment. The most typical pathogenic bacteria in bio-medical waste are of the genus Staphylococci, Bacillus and Streptococci, along with varying numbers of other common nosocomial pathogenic bacteria such as Klebsiella, Salmonella, Proteus and Enterobacter species (Alagoz et al., 2008 and Coker et al., 2009). However, the most prevalent bacteria found in clinical solid waste (CSW) are Staphylococcus aureus, Escherichia coli, Pseudomonas aeruginosa, and Bacillus cereus (Park et al., 2009).

\section{Materials and Methods}

The present study was conducted at the Animal biomedical waste disposal technology centre, Rajasthan University of Veterinary and Animal Sciences, Bikaner, India.

A total of 50 biomedical waste samples were collected from the various departments of CVAS, Bikaner viz. department of Veterinary Surgery, Veterinary Medicine, Veterinary Gynaecology and Obstetrics and department of Veterinary Pathology in sterilized yellow color coded biohazard bag as per BMW (Management and handling) rules, 2016. About 100-150 gram of biomedical waste samples were collected in pre sterilized yellow color coded bags and brought to the Animal biomedical waste disposal technology centre. Collected biomedical wastes included the animal tissues, body parts, blood, body fluids, infectious bedding of animal and carcasses. At the time of collection all the necessary precautions were followed by wearing protective clothing (apron), hand gloves, face mask, head cover and gum boot as prescribed in the BMW (Management and handling) rules, 2016.

\section{Isolation and identification of bacteria}

The Bio-medical waste samples were subjected to aerobic cultivation. Each Biomedical waste sample was streaked on Nutrient agar, plates in primary, secondary, and tertiary fashion in order to obtain isolated colonies of bacteria. These petri plates were incubated for $24 \mathrm{hr}$ at $37^{\circ} \mathrm{C}$. After $24 \mathrm{hr}$ incubation these isolated colonies were cultured on Mannitol salt agar (MSA), Eosine Methylene blue agar (EMB) and Mannitol egg yolk Polymyxin (MYP) agar plates respectively for isolation of Staphylococcus, Escherichia, and Bacillus and incubated for 24 hours at $37^{\circ} \mathrm{C}$. The growth was examined for the colonial morphology and pigmentation, and in order to obtain pure culture different types of colonies were subcultured on separate nutrient agar plates.

\section{Confirmation of the isolates by using primary and secondary biochemical tests}

The confirmation of the isolates such as Staphylococcus aureus, Escherichia coli and Bacillus spp. was done by using Gram's staining and biochemical tests provided in $\mathrm{HiStaph}^{\mathrm{TM}}$ Identification Kit ((HiMedia, Mumbai) for Staphylococcus, Hi25 Enterobacteriaceae Identification Kit (HiMedia, Mumbai) for Escherichia coli and HiBacillus ${ }^{\mathrm{TM}}$ Biochemical Test Kit (HiMedia, Mumbai) for Bacillus. 


\section{Results and Discussion}

The result of the present study reveals that frequency of isolated bacterial strains of the collected hospital wastes is depicted in (table 1 ; fig-1). In the present study out of 50 biomedical waste samples, 16 samples were found positive for Escherichia coli (32\%), 14 samples for Staphylococcus aureus (28\%) and 5 samples for Bacillus spp. (10\%). Colonies of Staphylococcus aureus on Mannitol salt agar and results of biochemical test depicted in (fig-2and 3). Escherichia coli on EMB agar results of biochemical test depicted in (fig4and 5) and Bacillus spp. on MYP agar results of biochemical test depicted in (fig-6 and 7) are shown, respectively.

The detailed results of various biochemical tests performed for Bacillus spp., Escherichia coli and Staphylococcus aureus are shown in (Table-2).

Table.1 Percentage of bacteria present in bio medical waste samples

\begin{tabular}{|l|c|}
\hline \multicolumn{1}{|c|}{ Identified bacteria } & Percentage of appearance \\
\hline Escherichia coli & $32 \%$ \\
\hline Staphylococcus aureus & $28 \%$ \\
\hline Bacillus cereus & $10 \%$ \\
\hline
\end{tabular}

Table.2 Biochemical characteristic of isolated bacterial strain (Bacillus spp., Staphylococcus aureus and Escherichia coli)

\begin{tabular}{|c|c|c|c|}
\hline Characterization & Bacillus spp. & $\begin{array}{c}\text { Staphylococcus } \\
\text { aureus }\end{array}$ & Escherichia coli \\
\hline Gram staining & + & + & - \\
\hline Colonies & Light pinkish & Yellow & Green \\
\hline Shape & rods & cocci & rods \\
\hline Catalase & + & + & + \\
\hline Coagulase & - & + & - \\
\hline Citrate utilization & + & - & - \\
\hline Nitrate reduction & + & + & + \\
\hline ONPG & - & - & + \\
\hline Vogus Proskaur test & + & + & - \\
\hline Indole & - & - & + \\
\hline Glucose & + & + & + \\
\hline Sucrose & + & - & - \\
\hline Lactose & - & + & + \\
\hline Mannitol & + & + & - \\
\hline Arabinose & + & - & - \\
\hline
\end{tabular}


Fig.1 Percentage of bacteria present in bio medical waste samples

\section{Percentage of bacteria present in bio medical waste samples}

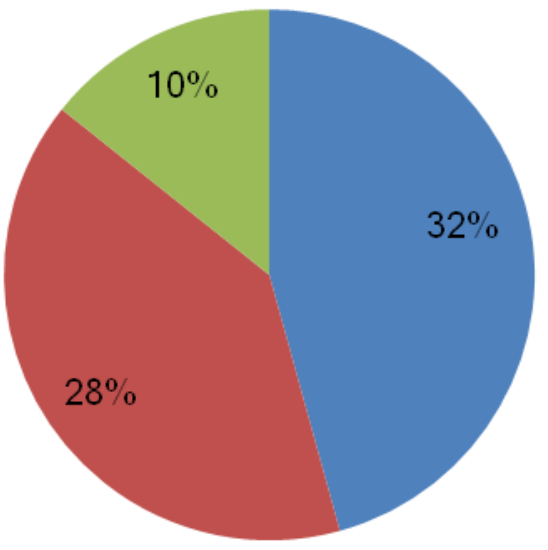

Escherichia coli

- Staphylococcus aureus

Bacillus cereus

Fig.2 Isolation of Staphylococcus aureus on Mannitol salt agar from Biomedical Waste Sample

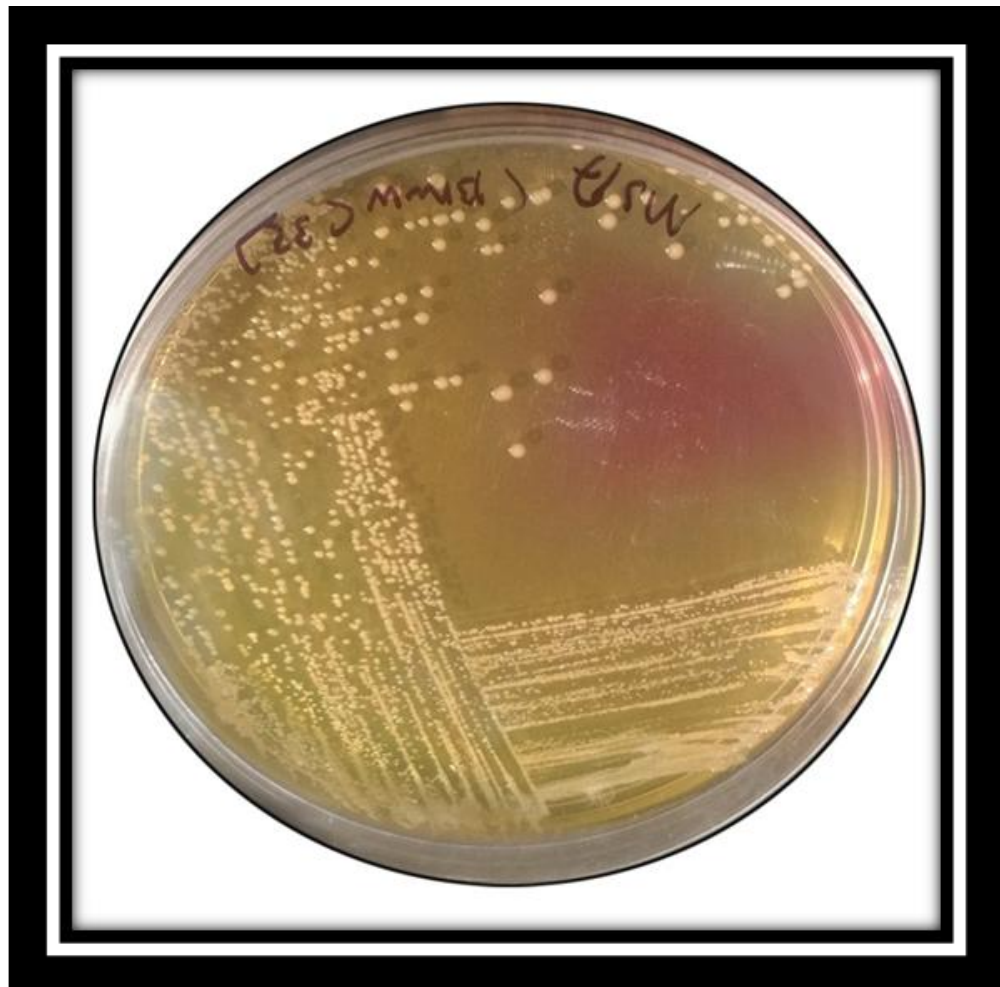


Fig.3 Results of biochemical tests for Staphylococcus aureus using HiStaph ${ }^{\mathrm{TM}}$ commercial kits

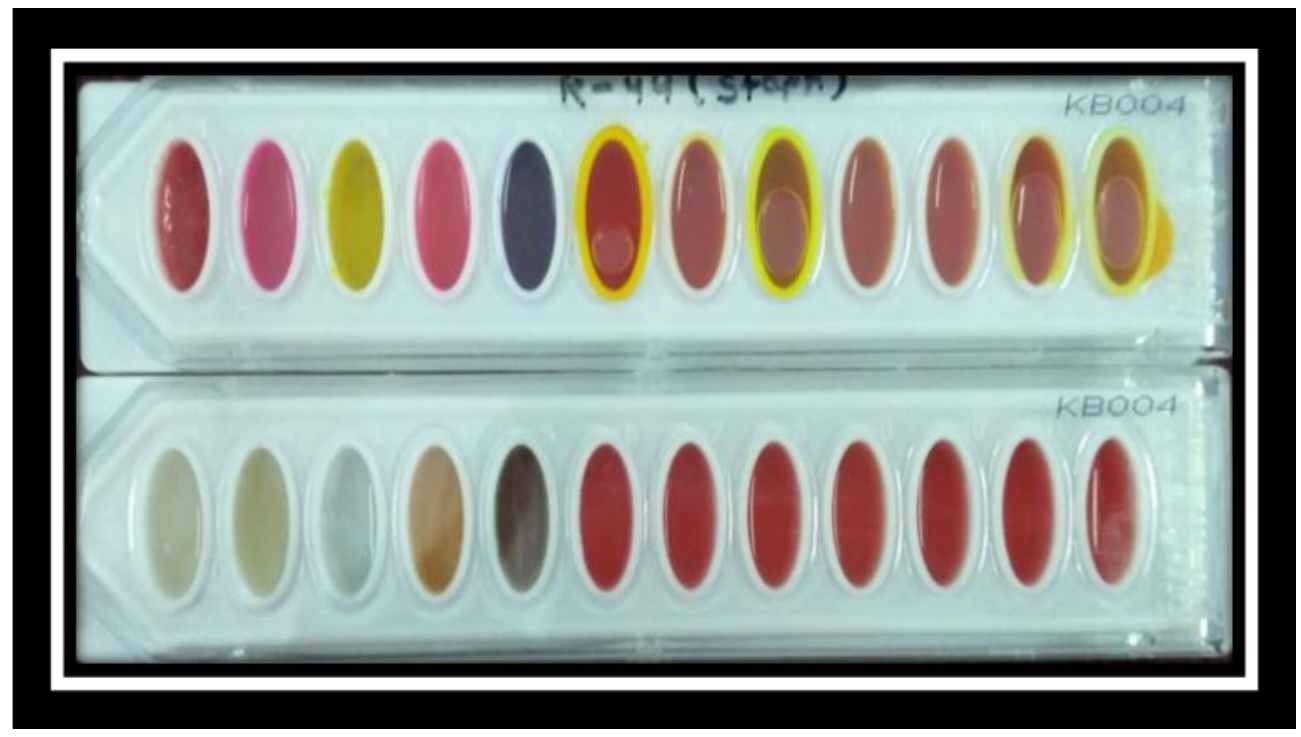

Fig.4 Isolation of Escherichia coli on EMB agar from Biomedical Waste Sample

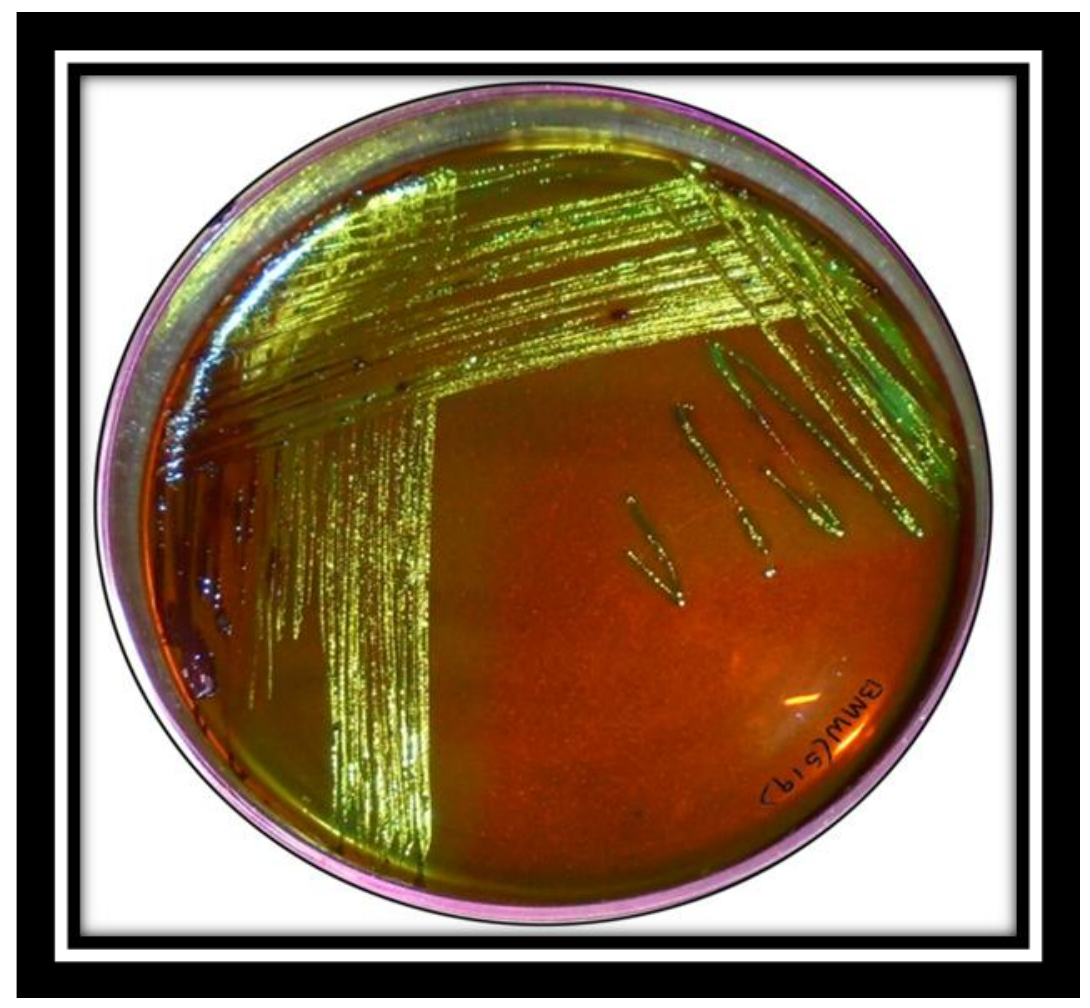


Fig.5 Results of biochemical tests for Escherichia coli obtained from HiE.coli ${ }^{\mathrm{TM}}$ commercial kits

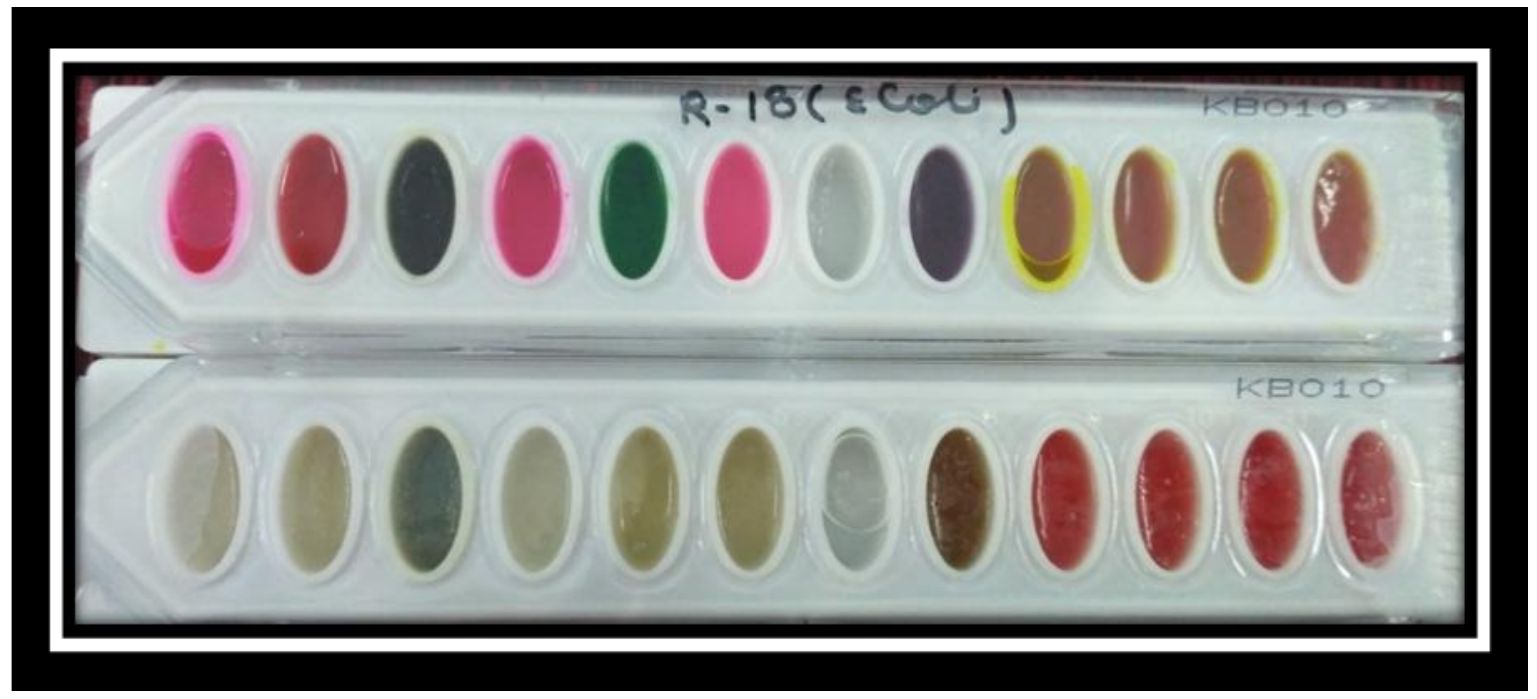

Fig.6 Isolation of Bacillus spp. on MYP agar from Biomedical Waste Sample

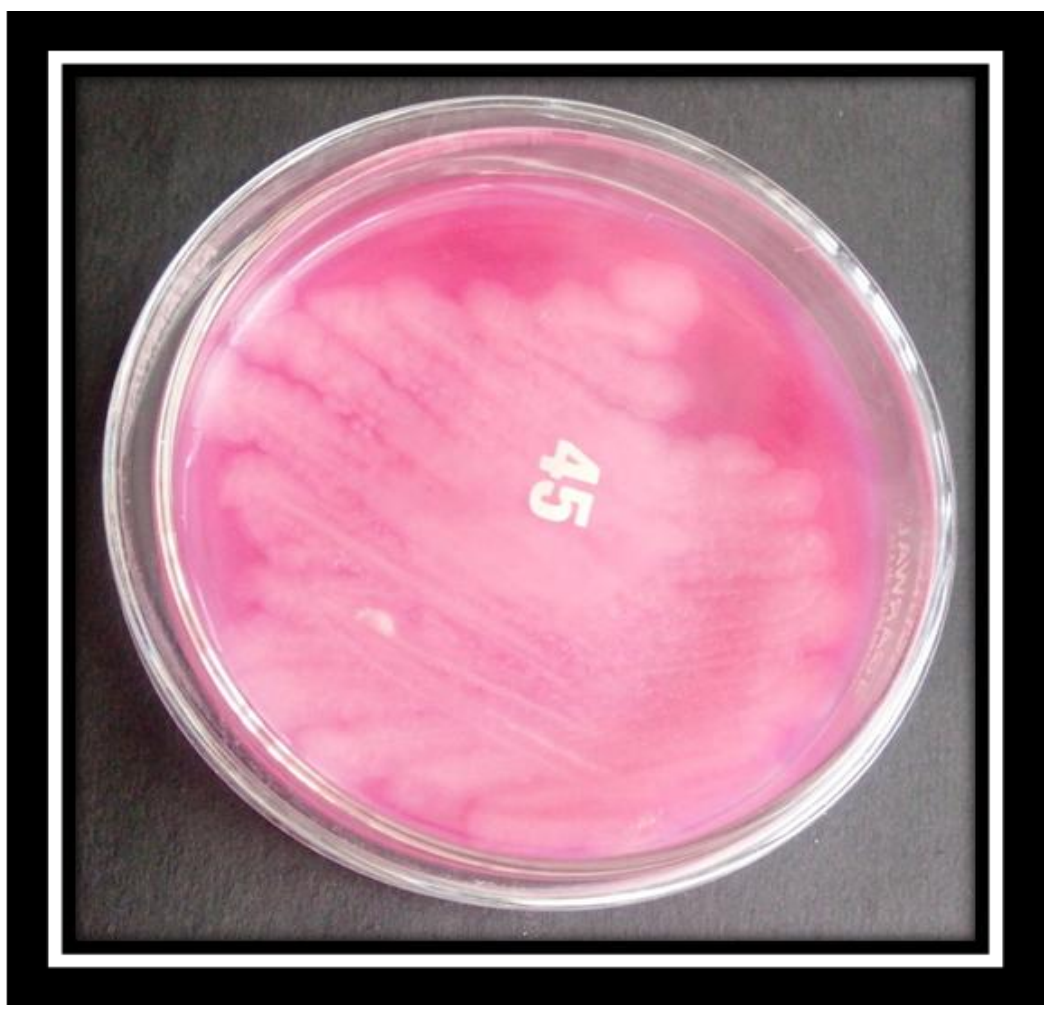


Fig.7 Results of biochemical tests for Bacillus spp. obtained from HiBacillu ${ }^{\mathrm{sTM}}$ commercial kits

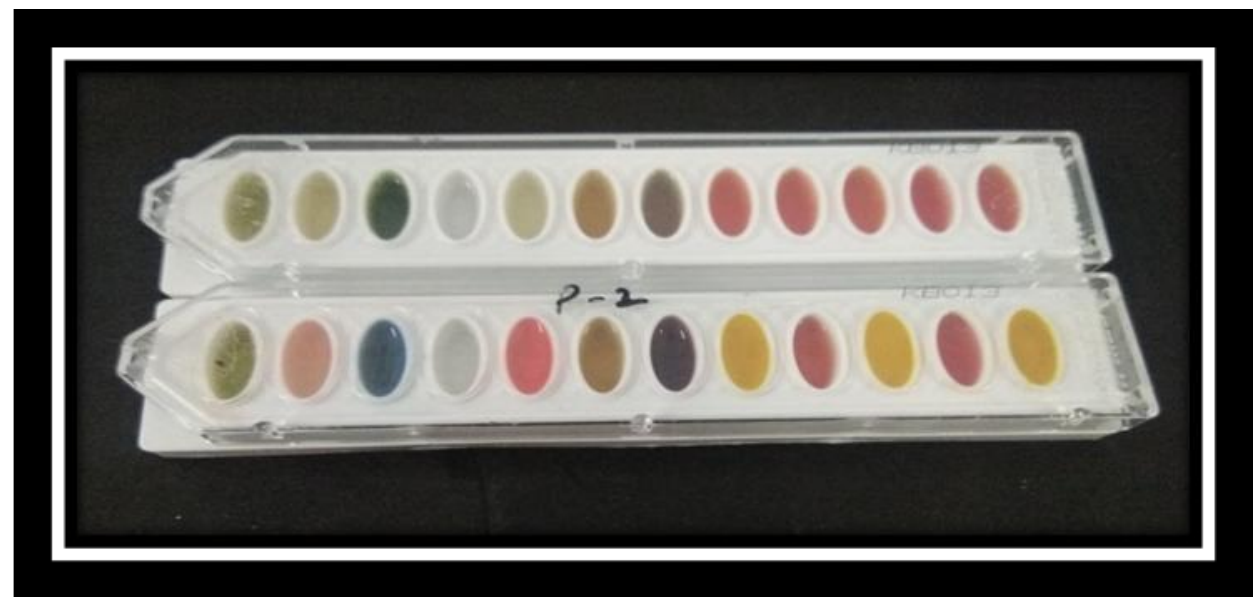

In the present study out of 50 biomedical waste samples, 16 samples were found positive for Escherichia coli (32\%), 14 samples for Staphylococcus aureus (28\%) and 5 samples for Bacillus spp. (10\%). Bacillus and Escherichia Coli was reported by Cook et al., (1964) while Liu and Chen (1980) reported Escherichia Coli. Ekundayo (1977) and Gray (1967) also reported the presence of Bacillus, Escherichia Coli and Staphylococcus in biomedical wastes. Rastogi et al., (2011) reported 18.38\% Staphylococcus aureus and $22.29 \%$ Escherichia coli which is lower than present investigation. Feleke et al., (2014) also isolated the lower results than present study which is Escherichia coli (11.5\%) and Staphylococcus aureus (8.2\%) from the 60 hospitals waste water samples. Faith et al., (2010) isolated the Escherichia Coli (50.00\%) which is higher and Staphylococcus aureus (14.67\%) which is lower than present results from municipal solid waste. According to Oyeleke and Istifanus (2009) the live pathogens found in hospital wastes, the most predominant (80$90 \%$ ) is the genus Bacillus with Staphylococci and Streptococci varying between 5 and $10 \%$, where as the most common pathogens are Staphylococcus aureus (from 2-10 colonies per gram of wastes). Tiku et al., (2018) also identified Staphylococcus, Streptococcus and Bacillus spp. from solid waste of General Hospital Calabar.

\section{Acknowledgement}

We extend our sincere gratitude to dean, College of Veterinary and Animal Science and director of research, Rajasthan University of Veterinary and Animal Sciences, Bikaner334001 for providing necessary facilities and funds to carry out this work.

\section{References}

Alagoz, A. Z. and Kocasoy, G. 2008. Determination of the best appropriate management methods for the healthcare wastes in İstanbul. Waste Management. 28: 1227-1235.

Coker, A., Sangodoyin, A., Sridhar, M., Booth, C., Olomolaiye, P. and Hammond, F. 2009. Medical waste management in Ibadan, Nigeria: Obstacles and prospects. Waste Management. 29: 804-811.

Cook, H. A., Cromwell, D. L. and Wilson, H. A. 1964. Microorganisms in house hold 
refuse and seepage water from Sanitary Landfills. Proceedings. West Virginia Academy of Sciences. 39: 107 - 114.

Ekundayo, J. A. 1977. Environmental consequences of the pollution of the Lagos Lagoon. Bull. Sci. Assoc. Nigeria. 3(2): 290 -299.

Faith, Efosa Oviasogie.; Christopher, Uche Ajuzie; Uyiosa, Glory Ighodaro. (2010). Bacterial Analysis of Soil from Waste Dumpsite. Arch. Appl. Sci. Res. 2(5):161-167.

Feleke, Moges. Mengistu, Endris.; Yeshambel, Belyhun and Walelegn, Worku. 2014. Isolation and characterization of multiple drug resistance bacterial pathogens from waste water in hospital and non-hospital environments, Northwest Ethiopia. BMC Res. Not. 7: 215.

Govt of India. Ministry of Environment and Forests Gazette notification No 460 dated July 27. New Delhi 1998; 10-20.

Gray, K. R. 1967. Accelerated Composting. Compost Science. 7(3): 29 - 32.

Jang, Y. C., Lee, C., Yoon, O. S. and Kim, H. 2006. Medical waste management in Korea. J. Environ. Manag. 80: 107-115.

Liu, K. X. and Chen, G. Q. 1980. Studies on the biogas fermentation of the Chinese Rural Areas. In: S. O. Emejuaiwe, O. Ogunbi, and S. O. Sanni (Editors). Global Impact of Applied Microbiology
(GIAM VI). Academic Press London; Nemathaga, F., Maringa, S. and Chimuka, L. 2008. Hospital solid waste management practices in Limpopo Province, South Africa: A case study of two hospitals. Waste Manag. 28: 1236-1245

Omrani, Q., Etabi, F., Sadeghi, M. and Banaei, B. 2007. The Comparison of Technical, Environmental and economical Aspects of Autoclaving, Incineration and Landfilling in Medical wastes Disposal. Wastes management law, Environ Sci \& Tech. 2: 1383.

Oyeleke, S. B. and Istifanus, N. 2009. The microbiological effects of hospital wastes on the environment African Journal of Biotechnology. 8(22): 62536257.

Park, H., Lee, H., Kim, M., Lee, J., Seong, S.Y. and Ko, G. 2009. Detection and hazard assessment of pathogenic microorganisms in medical waste. $\mathrm{J}$. Environ. Sci. Health. 44: 995-1003.

Rastogi, V., Rastogi, P. and Bhatia, S. 2011. Bacteriological Profile of Biomedical Waste: Management Guidelines. J Indian Acad Forensic Med. 33: 2.

Tiku, D. R., Asikong, E. B. E. and Bassey, I. U. 2018. Influence of biomedical waste on nosocomial infections. International journal of healthcare sciences. 6(2): 324-329.

\section{How to cite this article:}

Rajani Joshi, Rakesh Rao, Manohar Sain, Pankaj Mangal and Paramjeet Kaur. 2020. Microbial Assessment of Bio-medical Waste from Different Health Care Units of Bikaner. Int.J.Curr.Microbiol.App.Sci. 9(01): 1808-1815. doi: https://doi.org/10.20546/ijcmas.2020.901.202 